The impact of competition and cooperation on the performance of a retail agglomeration and its stores

(Published in Industrial Marketing Management in 2015; DOI: 10.1016/j.indmarman.2015.07.010)

Christoph Teller*, Andrew Alexander, Arne Floh

Surrey Business School, University of Surrey, United Kingdom;

*, corresponding author, The Surrey Business School, University of Surrey, GU2 7HX

Guildford, United Kingdom; Tel: +44 (0)1483 68 3981, Fax: +44 (0)1483 686346, e-mail:

c.teller@surrey.ac.uk;

Reference of the original article: Teller, Christoph, Alexander, Andrew, Floh, Arne. 2015. The impact of competition and cooperation on the performance of a retail agglomeration and its stores. Industrial Marketing Management, in print; DOI: 10.1016/j.indmarman.2015.07.010. 


\title{
The impact of competition and cooperation on the performance of a retail agglomeration and its stores
}

\begin{abstract}
Stores in retail and other service agglomerations, such as high streets and shopping malls, compete with each other for customers. Yet they may also cooperate with each other in relation to operational and marketing matters within the agglomeration in which they are located. The aim of this paper is to investigate the impact of both competition and cooperation, i.e. coopetition, on agglomeration and store performance. Drawing on the network debate, this paper develops a conceptual model and tests it in three distinctive agglomerations, each in an urban setting, namely first- and second-order high streets as well as an inner-city retail and service cluster. A total of 277 store managers served as key informants in our survey. Variancebased structural equation modelling reveals that both competition and cooperation improve agglomeration performance directly. Despite competition having a negative direct effect on stores' performance, the overall effect is insignificant. Cooperation affects store performance positively but only indirectly. The contribution of this paper is to reveal and substantiate the complex nature and benefits of the effects of the coopetition of stores located within agglomerations. More widely it underlines the importance of managers of agglomerations understanding the differing effects of competition and cooperation and using this understanding in their management decision making.
\end{abstract}

Keywords: retailer competition; retailer cooperation; high street; town centre; shopping centre; network; agglomerations; 
Research highlights:

- Competition and cooperation between stores increase agglomeration performance.

- There is a positive spill-over effect between agglomeration and store performance.

- Cooperation increases store performance indirectly via agglomeration performance.

- The spill-over effect nullifies competition's negative impact on store performance.

- Coopetition capabilities of stores enhance competitiveness of an agglomeration. 


\section{The impact of competition and cooperation on the performance of a retail agglomeration and its stores}

\section{Introduction}

Competition and cooperation in agglomerations: The competition between retail and service agglomerations (hereafter agglomerations) of the same and different types and sizes, for example high streets and shopping malls, is increasing (Guy, 2007; Haytko, 2004; Teller, 2008). Furthermore, store-based retailing as a whole is coming under pressure from online retail and service operations (Field, 2006; Mintel, 2014). Thus, for managers of retail and service organisations operating stores in agglomerations, and for the management of these agglomerations, the question of how to most effectively utilise resources and capabilities derived from the agglomeration to increase performance levels and competitiveness has become crucial and prevalent (Dennis, Marsland, \& Newman, 2005; Konopa \& Zallocco, 1981).

Independent of the agglomeration format, the reason why retail and service organisations (hereafter retailers) locate stores in agglomerations, and why consumers patronise them, typically lies in the benefits that arise both from the proximity of the retailers to one another (Knoben \& Oerlemans, 2006) and from their generic nature as a form of horizontal inter-organisational network. Such networks produce synergies and encourage cooperation due to the retail and service stores' close proximity to one another. Yet, alongside the potential benefits from cooperation, retailers and their stores find themselves competing with each other for a share of the money and dwell time spent by customers during trips to the agglomeration (Oppewal and Holyoake, 2004). Such competition can have positive effects for customers but negative effects for retailers. 
The managers of agglomerations and the managers of retail stores located in these agglomerations need to be aware of the possible tensions stemming from this combination of cooperation and competition. In the context of an agglomeration in which stores compete with one another, store managers also develop cooperative inter-organisational relationships. Such relationships include those with other stores that lead to collaboration in areas that enhance the agglomeration's and consequently the stores' attractiveness to customers and hence their performance. Such cooperation typically focuses upon two aspects. The first is the direct input of resources as part of collaboration in agglomeration-wide marketing initiatives and events, for example malls' seasonal events, and promotional schemes such as mall loyalty cards. The second relates to the pooling of financial resources, for example to finance the employment of site management for the agglomeration, and to enable the purchase of so-called hard services (for example, fabric maintenance) and soft services (for example, cleaning, security and marketing) at the agglomeration level. In purpose-developed and managed shopping centres (that we term created agglomerations), this is likely to result from the payment of a service charge to the centre's management or operator. In a town centre shopping environment (that we term evolved agglomerations), it may take the form of either a voluntary or mandatory levy, depending on the type of centre management scheme in operation. In evolved agglomerations in which centre management initiatives are at an early stage of development store managers may be directly involved in the purchasing activity. For the managers of agglomerations the need to practise careful co-management of the potentially opposing forces of competition and cooperation can extend to the identification and selection, and respectively the termination of (the lease of), new and existing stores. In this regard, for both store managers and managers of agglomerations we identify a context that is broadly analogous with debates in the marketing literature on the purchasing-marketing interface (Lindgreen, Vanhamme, van Raaij, \& Johnston, 2013; Sheth, Sharma, \& Iyer, 2009), 
although we acknowledge the distinctions between "horizontal" and "vertical" interdependence between firms and the associated resource pooling (e.g. Grandori \& Soda, 1995).

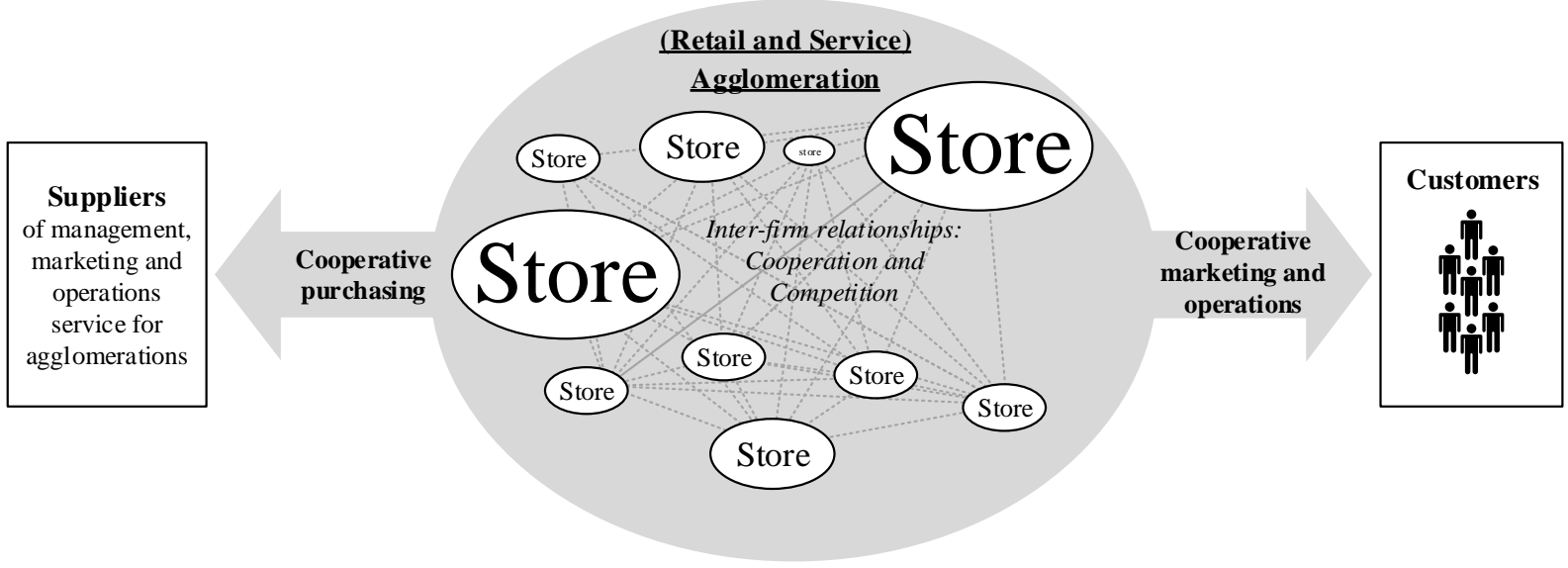

Figure 1: Cooperative purchasing, marketing and operations in a competitive network environment

Here, then, the perspective goes beyond the dyadic view, for example buyer-supplier or retailer-customer, with a network perspective required if we are to understand the complexities emerging from inter-firm relationships that facilitate the integration of resources and thus cooperation in the areas of purchasing, marketing and operations (Lavie, 2006; Oh, Teo, \& Sambamurthy, 2012; Schoenherr et al., 2012). Cooperation in a competitive environment such as an agglomeration is focused towards the customers and thus requires a close integration between the demand (marketing and operations) and the supply (purchasing) side of the network (Zondag \& Ferrin, 2014; see Figure 1).

Our concern, then, is to better understand the effects of competition and cooperation on store performance in an agglomeration, and thus their implications for the managers of stores and those of agglomerations who seek customer value creation opportunities.

Research gap: The literature has addressed the importance of retailer competition as a characteristic of the store mix in agglomerations from a consumer's point of view (e.g. Yiu \& 
$\mathrm{Xu}, 2012$ ). Cooperation between stores has been investigated within the remit of place, town and shopping centre marketing and management (e.g. Teller \& Elms, 2012). Surprisingly, to our knowledge, previous research on agglomerations has not looked into the link between competition and cooperation. Even more importantly, prior research does not provide answers on whether retailers that are the key nodes of agglomerations such as shopping centres and high streets should invest resources in collaborating with other stores in the centre, and whether they should encourage the agglomeration management to increase competition, for example by actively admitting competing stores.

Given the characteristics of agglomerations as a form of horizontal interorganisational (service delivery) network (Tax, McCutcheon, \& Wilkinson, 2013), this paper draws in particular on the network literature. It aims to (1) evaluate the effects of competition and cooperation on the performance of stores in agglomerations, and (2) assess the implications of competition and cooperation between stores in an agglomeration for the managers of the stores, and for those with direct managerial responsibility for the agglomeration itself. The main contribution of this paper for theory and practice lies in its emphasis on the complexity of the competition and cooperation between stores within an agglomeration, and the importance of effective co-management of competition and cooperation by store and agglomeration managers.

The structure of this paper is as follows: Following on from these introductory remarks, the next sections analyse some of the literature that informs this study and present the conceptual model and study hypotheses that we test later in the paper. The subsequent sections concentrate on the methodology of the empirical study and a description of the results. The paper closes with a discussion of the major implications for theory as well as practice, a critical review of the study's limitations, and a recommended research agenda. 


\section{Agglomerations as (service delivery) networks}

\subsection{Agglomeration characteristics}

The presence of a group of firms in a geographically defined unit, such as a building, street or block, can be called an agglomeration (Knoben \& Oerlemans, 2006). Consequently, retail and service agglomerations represent retail and service stores located in close proximity to each other. Together the firms make up what Kalen (1966) terms a "combined department store", that is, interlinked units cooperating without losing their independence but also competing for the same customers. Citing the work of Williamson, Dyer and Singh (1998, p. 662) refer to relation-specific assets as deriving from site specificity, "the situation whereby successive production stages that are immobile are located close to one another" (in our context how colocated service provision enables customer value creation opportunities), as well as from physical asset specificities (for example agglomeration facilities) and human asset specificities (for example dedicated marketing partnerships).

A transfer of Brass, Galaskiewicz, Greve, and Tsai's (2004) view on networks to the setting of agglomerations emphasises that nodes (i.e. stores) and actors (i.e. store managers), as representations of retail and service organisations, are embedded in a network of interconnected formal and informal relationships (see Figure 1). These relationships offer opportunities, for example the leveraging of synergies, but also constraints, for example the imposition of infrastructural guidelines. Stores in agglomerations “ “.. are connected together to form quasi organisations” (Håkansson \& Ford, 2002, p. 133). Agglomerations represent branded place products (Balakrishnan, 2009) that consumers perceive as entities (Haytko, 2004).

We follow Grandori and Soda (1995) in being interested in networks "as modes of organising economic activities through inter-firm coordination and cooperation" (p. 184). For inter-organisational networks in general, the benefits that an organisation seeks by being part 
of a network are maximised efficiencies, synergies and organisational learning through the sharing of resources (Chetty \& Wilson, 2003). Further synergistic effects, also called agglomeration effects (Oppewal \& Holyoake, 2004), that organisations can achieve by collaborating within an agglomeration such as a shopping centre include, for example, shared parking facilities, enhanced footfall, and integrated centre-wide marketing and management (Teller \& Schnedlitz, 2012). Individual organisations' abilities to realise these benefits depend upon a combination of network structure effects and focal organisation characteristics (Zaheer \& Bell, 2005).

To differentiate between different kinds of retail and service agglomerations, we propose a simple typology that distinguishes between (1) evolved retail and service agglomeration formats such as inner-city retail clusters or town centres and (2) created retail and service agglomeration formats such as shopping malls, factory outlet centres, strip malls and other kinds of shopping centres (Teller, 2008). Evolved retail and service agglomerations represent emergent networks that are essentially self-organising and have typically evolved in a bottom-up fashion from bilateral interactions (Wilkinson \& Young, 2002). There have been attempts, some now quite long-standing, to enhance the management and coordination of such evolved agglomerations through various forms of town centre management (Warnaby, Alexander, \& Medway, 1998). Whilst, typically, these do not permit the level of management design and control that is possible within purpose-developed shopping centres (the created agglomerations), they can occasionally extend to more strategic initiatives. One might think of a created agglomeration as a form of strategic network or value net, consisting of a predetermined set of stores and infrastructure, each having clear roles for customer value creation within the network (Möller \& Rajala, 2007). Such networks have clear structures, roles and goals based on negotiation, and a central management that is clearly empowered in 
determining how the network and its nodes (i.e. the stores in an agglomeration such as a shopping centre) will attempt to create value for their customers (Möller \& Rajala, 2007).

\subsection{Agglomeration resources and capabilities}

The literature on networks has rarely considered horizontal inter-organisational retail and service networks of the kind of interest here (e.g. Brass et al., 2004). A quite recent exception is the work of Tax et al. (2013), who conceptualise the phenomenon of service delivery networks. Retail and service agglomerations such as shopping centres qualify as service delivery networks in that they are sets of interdependent operations that - in the view of consumers - provide holistic service experiences.

Individual retailers clearly represent key nodes in agglomerations such as shopping centres. The resource-based view of the firm (e.g. Barney, 1991; Grant, 1991; Peteraf, 1993; Wernerfelt, 1984) considers how resources and related capabilities can lead to competitive advantage for organisations, and is hence complementary to our thinking about network resources and benefits (Dyer \& Singh, 1998). For retailers in shopping centres the relevant resources and capabilities are diverse, and as we discuss below they may spill over onto the wider agglomeration (Arentze, Oppewal, \& Timmermans, 2005). First there are the resources and related capabilities that directly underpin the competitive performance of the retailer, including its competition with other retailers in the same centre (Teller \& Schnedlitz, 2012). These include critical resources and capabilities across the supply chain that, in chain store operations, may emerge from different parts of the organisation's operational structure and not necessarily from within the store, for example expertise in the buying process. Second there is a quite different set of resources and related capabilities that underpin the cooperative performance of the retailer within the agglomeration. These include relational capabilities such as the capabilities of store-based managers and employees to interact effectively with agglomeration management personnel, and those of other stores, for the shared benefit of the 
agglomeration (Teller \& Alexander, 2014). The competitiveness and performance of agglomerations such as shopping centres rest heavily upon the resources and capabilities of the retailers therein, although clearly we also need to be mindful of the level of resources and capabilities that the agglomeration management itself has for exploiting the retailers' resources and capabilities.

To conclude, the network and resource-based views prove suitable for describing the interplay of the competition and cooperation between stores in agglomerations such as shopping centres. Together they help us to understand how organisations in an agglomeration might generate competitive advantage both for themselves and for the agglomeration by providing enhanced opportunities for customer value creation. Consequently, this provides the theoretical lens for the investigation of our research aims and for the setting up of a conceptual model.

\section{Conceptual model}

Inter-organisational networks such as agglomerations can help to increase organisational survival rates and the performance levels of individual actors (Brass et al., 2004; Wilkinson \& Young, 2002). Both the retail managers of stores located in agglomerations and the managers of the agglomerations themselves need to (1) understand their key resources and resource utilisation relative to those of their competitors and (2) appreciate the complex links between the different types of resources and capabilities within the agglomeration, in order to increase their operational effectiveness (Grant, 1991; Lavie, 2006). The performance of an agglomeration refers to its attractiveness as reflected by the customers, for example through satisfaction or loyalty, as well as the effectiveness and efficiency of its operations, as indicated for example by sales, market share, spending per customer, footfall or new customer acquisition, relative to competitors' operations (e.g. Vorhies \& Morgan, 2005). From a service delivery network point of view, the whole set of service units - in the context 
of agglomerations, the stores - contributes to a holistic customer experience that enhances those service units' attractiveness to customers. This synergetic effect, variously labelled “gravity” (Reilly, 1931), "attraction” (Nevin \& Houston, 1980) or "attractiveness" (Teller \& Reutterer, 2008), drives the performance of agglomerations, which then spills over onto their stores (Swaminathan \& Moorman, 2009). Such close interdependence between a store and its spatial environment is reflected in our first hypothesis:

$H_{1}$ : The greater the agglomeration performance, the higher is the store performance.

However, the store performance might not mirror that of the agglomeration. In the case of some stores, for example anchor stores or key tenants that generate footfall for the agglomeration or that are sited in a more attractive or prime location within the agglomeration, a typical scenario could be that such stores outperform the agglomeration as a whole. Thus these stores benefit less from the agglomeration; i.e. the spill-over effect $\left(\mathrm{H}_{1}\right)$ is lower (Finn \& Louviere, 1996; Teller \& Schnedlitz, 2012). To the contrary, a store that is, for example, more dependent upon other stores within the agglomeration for footfall generation, or one that is sited in a less attractive location, for example a more peripheral location, might underperform the whole network. Here the spill-over effect $\left(\mathrm{H}_{1}\right)$ is higher and these stores benefit from the agglomeration to a disproportionate degree. We thus propose that the importance of the store in terms of footfall generation and the attractiveness of the intraagglomeration location moderate the performance spill-over effect as outlined in our first hypothesis. The two moderating hypotheses appended to $\mathrm{H}_{1}$ are as follows: $H_{1 a}:$ The more attractive the location of a store within an agglomeration, the lower is the impact of the agglomeration performance on the store performance. $H_{1 b}$ : The higher the capacity of a store to generate footfall, the lower is the impact of the agglomeration performance on the store performance. 
Dyer and Singh (1998) argue that, for firms within a network, the ability to build relationships with each other and collaborate enables them to develop a competitive advantage. They thus see collaboration as a capability that increases firms' individual - and thus the network's - performance and profitability. This is achieved through investments in relation-specific assets, together with knowledge exchange and joint learning, the leveraging of complementary resource endowments through collaboration, and effective governance that reduces transaction costs (Dyer \& Singh, 1998). In the context of agglomerations, a key resource is the proximity between stores. According to Knoben and Oerlemans (2006), spatial proximity is the most crucial of the dimensions in terms of driving cooperation. The motives behind cooperation in inter-organisational networks such as agglomerations include acquiring resources, reducing uncertainty, enhancing legitimacy and attaining collective goals (Brass et al., 2004). Cooperation between the stores in agglomerations, for example in terms of the collaborative funding and management of resources and of formal and informal knowledge sharing, is one of the core capabilities of agglomerations, increasing their performance levels and thus competitiveness (Lavie, 2006; Teller \& Schnedlitz, 2012). These beneficial agglomeration effects again spill over onto individual nodes (stores) within the network. In other words, relationships and collaborations between organisations in networks, including those between stores in agglomerations, represent a significant resource that can result in “super normal profit returns" (Dyer \& Singh, 1998, p. 676). This leads to the next two hypotheses:

$\mathrm{H}_{2}$ : The greater the cooperation between stores in an agglomeration, the higher is the agglomeration performance.

$H_{3}$ : The greater the cooperation between stores in an agglomeration, the higher is the store performance. 
The competition between stores in an agglomeration is another outcome of the spatial proximity of such stores (Teller, 2008). The depth and width of the store range within the agglomeration influences the intensity of the competition (Yiu \& Xu, 2012). This effect can be seen when an agglomeration's management admits new stores to the network. The depth of the store mix reflects the extent to which the stores appeal to the same wants and needs of the customers, such as clothing, grocery or entertainment. Width refers to the complementarity of stores targeting diverse wants and needs. In both cases - but in terms of depth more than width - stores compete for the same agglomeration customers and a share of their awareness, interest, attention, time and expenditure while on a multi-purpose trip to the retail agglomeration (Arentze et al., 2005). Competition, for example at a promotional or a price level, creates benefits for customers. This enhances the attractiveness of agglomerations to customers, and thus their performance (Oppewal \& Holyoake, 2004). Clearly not all stores in an agglomeration may benefit from such competition and, on the contrary, they may be under pressure to enhance their marketing efforts, for example in terms of price discounts or promotional events, in order to win as large a share as possible of the time and money customers spend within the agglomeration (Teller \& Schnedlitz, 2012). Such competition could result in a decrease in the performance of a store. Thus, competition may be an advantage for an agglomeration in offering value-creating opportunities to its customers yet a disadvantage for its stores. We thus propose the following:

$H_{4}$ : The greater the competition between stores in an agglomeration, the higher is the agglomeration performance.

$H_{5}:$ The greater the competition between stores in an agglomeration, the lower is the store performance.

To conclude the discussion around the five hypotheses with respect to the network and resource-based views, Figure 2 illustrates the conceptual model underpinning this study. 


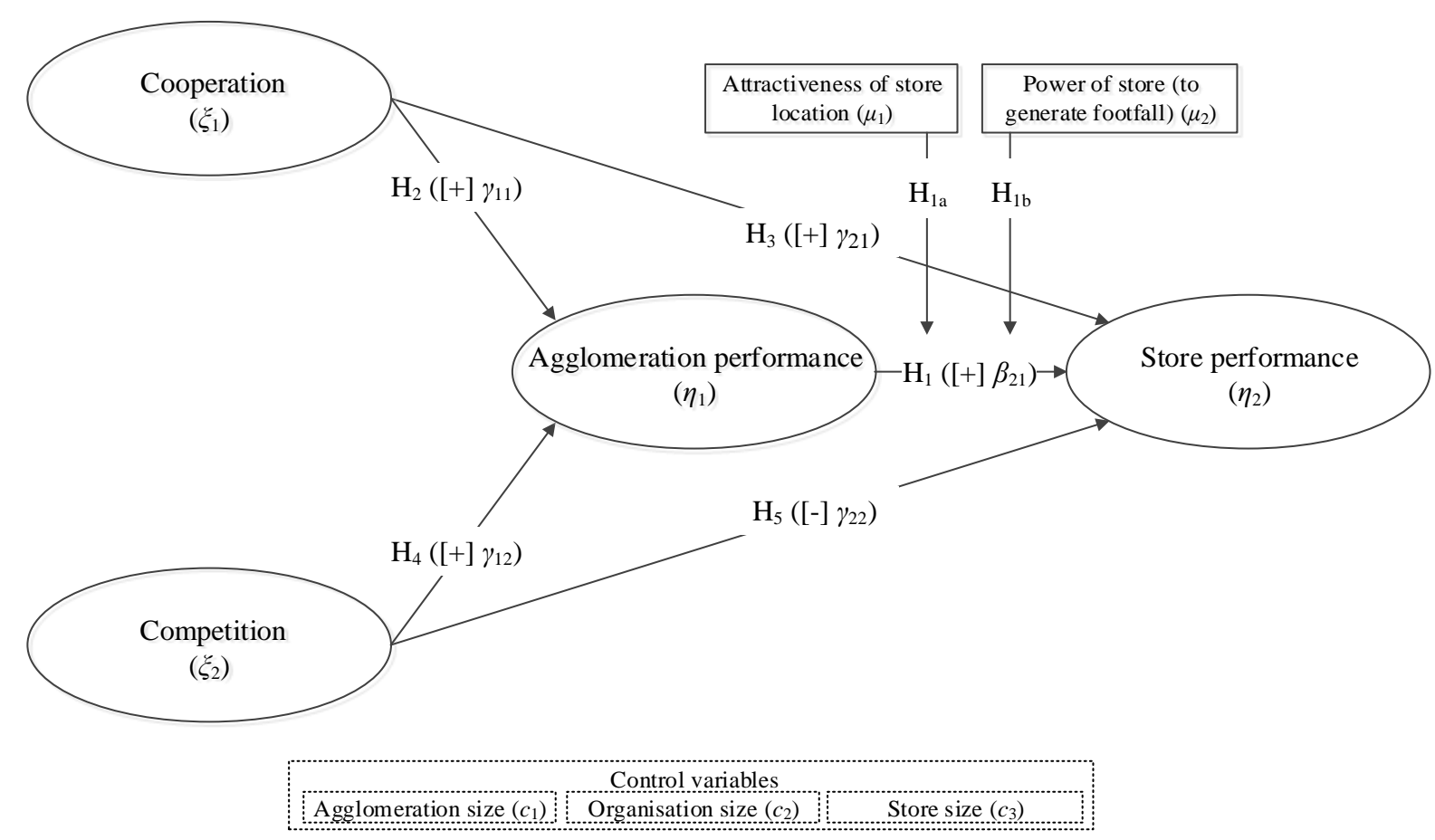

Figure 2. Conceptual model

In addition to the five direct effects, the model also proposes indirect links between cooperation, competition and store performance, mediated by agglomeration performance. It also suggests that the coexistence of cooperation and competition affects performance (e.g. Wilkinson \& Young, 2002). From a store perspective, managers find themselves in a (strategic) alliance, torn between cooperation and competition with other stores (of any kind) within the agglomeration (Das \& Bing-Sheng Teng, 2000). Brandenburger and Nalebuff (1998) term this phenomenon coopetition and highlight the challenges, and in particular the opportunities, in such adversarial as well as friendly relationships between organisations (see also Chen, 2008; Clarke-Hill, Li, \& Davies, 2003; Gnyawali \& Park, 2011). Bengtsson and Kock (2000) underline the complexity of coopetitive relationships when they say that “...they consist of two diametrically different logics of interaction" (p. 415; see also Bengtsson \& Kock, 1999). An important task of agglomeration management is to co-manage the competition and cooperation between stores in order to elevate performance and competitiveness. Managers of retail stores in agglomerations, and agglomeration managers 
themselves, require a clear understanding of the effects of competition and cooperation within the agglomeration on store performance, including any spill-over effects on store performance from wider agglomeration performance. Such an understanding will help them to cope with the complexity of the relationships between the nodes in inter-organisational networks (Piercy, 2009).

\section{Methodology}

\subsection{Empirical settings}

Following the suggestion of Möller and Rajala (2007), this empirical research uses different empirical agglomeration settings to investigate the impact on performance of network resources and capabilities related to cooperation and competition. Our study involves three evolved inner-city agglomerations. All of them are located in the same urban catchment area of a major European city with just fewer than two million inhabitants. The retail setting can be described as highly developed and characterised by a high density of stores. As in many European cities, these long-established inner city retail locations face increasing competition from a variety of peripherally located shopping centres that are a characteristic of the decentralisation of retailing, and more recently from internet retailing. Nevertheless, the agglomerations under investigation here benefit from well-organised public transport systems, and offer shoppers a distinctive atmosphere, partly created by the appealing architecture in each of these public spaces. The populations of interest include all retail and service stores located in each of the three agglomerations.

The first agglomeration is a first-order high street with a super-regional catchment area, comprising around 390 retail and service stores (in the main parade and within one block of it). The second, a pedestrianised agglomeration, is a typical upmarket inner-city retail cluster of 200 stores, again with a super-regional catchment area. Compared to these 
two very successful and high-performing agglomerations, the third is a second-order high street with around 160 stores, which is struggling to attract customers and (anchor) tenants to the same degree as the other two. It has a city-wide catchment area. The competition between the three agglomerations is limited.

\subsection{Survey approach}

To empirically investigate the conceptual model and to test the hypotheses, we conducted a survey targeting the managers of stores as key informants. According to Lusch and Serpkenci (1990), store managers "occupy an indispensable boundary role between the corporate organisation, the store operations, and the marketplace" (p. 99). This is in line with recent findings of Teller and Alexander (2014), who found store managers to be valuable sources of managerial information on store environments, such as agglomerations, store operations and (agglomeration) customers. Consequently, we see store managers as experts and thus as suitable informants (e.g. Campell, 1955) who have access to information regarding their agglomeration, their store and their customers because of their boundary-spanning role between the retail management, the shopping centre management and the customer. Our respondents were asked to complete a structured, self-administered questionnaire containing 41 questions using nominal, ordinal as well as metric scales.

Given the sizes of the three populations, we decided that it was feasible to conduct a census in the selected agglomerations and thus to attempt to include all stores, as represented by the store managers. To maximise the response rate and minimise the negative consequences of non-response error, we followed the tailored design method (TDM) for self-administered surveys (Dillman, Smyth, \& Christian, 2009). Research assistants visited the agglomeration in order to record details of the stores in the population and to obtain store managers' commitment to participate in the survey. This personal approach to the contacting of 
respondents was aimed at minimising issues related to the use of single informants (e.g. Kumar, Stern, \& Anderson, 1993) in our study, bearing in mind the limited size of many of the retail operations in our urban areas (see Table 1). The research assistants provided each store manager with a printed version of the questionnaire, collected it ten days later, and checked it for completeness. After the first round of store visits, the following number of questionnaires had been distributed: 320 in the first agglomeration, 160 in the second and 147 in the third. After two reminder rounds, we ended up with 170 usable questionnaires in the first, 64 in the second and 43 in the third agglomeration - satisfactory response rates of 53\%, $40 \%$ and $29 \%$ respectively. The most frequent reasons targeted respondents gave for not completing the questionnaire were a lack of time and a lack of interest in the study.

To test for non-response errors we followed the procedure suggested by Wagner and Kemmerling (2010). More specifically, we compared the key variables used in our model estimation (see appendix) between early and late respondents. $t$-tests did not reveal any significant differences between the two groups $\left(t_{(138)}<1.977\right)$. Furthermore, we compared the store sizes (big/small) and the main retail and service sector affiliations of the surveyed stores with those of the whole populations (see Table 1). A chi-square test did not reveal any significant differences $\left(\chi^{2}(1)<3.841\right)$ in any of the three agglomeration settings. Overall, we conclude that our samples represent the store range across the three agglomerations and that our data are not affected by non-response error.

\subsection{Respondents and store profiles}

The stores represented by our respondents provided a quite heterogeneous mix of retail and service sectors. In terms of numbers, stores selling apparel (32.9\%), footwear (8.7\%) and jewellery (watches) $(8.3 \%$ ) dominated the sample overall. Almost six out of ten stores (57.8\%) belonged to micro-enterprises employing less than nine people. Only $15.2 \%$ of the 
surveyed businesses had more than 250 members of staff. The average store size was 2,667.3 $\mathrm{ft}^{2}$ (standard deviation, 4,166.7 $\mathrm{ft}^{2}$ ) and the average number of daily sales transactions per store was 166.3 (standard deviation, 286.4). Most of the respondents (83.8\%) saw their stores as benefitting from being part of a wider agglomeration in terms of the footfall generated by other stores. $76.5 \%$ of our respondents rated the location of their store as being relatively more attractive (ratings greater than 0 on a bipolar seven-point rating scale, ranging from -3 , worst location, to +3 , best location) than all the other locations within their agglomeration. $26.7 \%$ of our respondents not only managed their store but also owned the business. Table 1 provides an overview of the characteristics of each of the agglomerations studied. Overall, we can conclude that stores in the second-order high street were typically significantly smaller (in square footage) and had fewer transactions than those in the two larger agglomerations. 
Table 1. Characteristics of the stores that responded to the survey

\begin{tabular}{|c|c|c|c|c|}
\hline Agglomeration & $\begin{array}{l}\text { AGG1. First-order } \\
\text { high street } \\
(\mathrm{n}, 170)\end{array}$ & $\begin{array}{l}\text { AGG2. Upmarket } \\
\text { inner-city retail } \\
\text { cluster }(n, 64)\end{array}$ & $\begin{array}{l}\text { AGG3. Second-order } \\
\text { high street }(\mathrm{n}, 43)\end{array}$ & Difference \\
\hline $\begin{array}{l}\text { Store's main affiliation to a retail/service } \\
\text { sector (top } 3, \% \text { ) }\end{array}$ & $\begin{array}{l}\text { Apparel, } 31.8 \\
\text { Footwear, } 7.6 \\
\text { Jewellery, } 6.5\end{array}$ & $\begin{array}{c}\text { Apparel, } 43.8 \\
\text { Jewellery, } 15.6 \\
\text { Footwear, } 7.8\end{array}$ & $\begin{array}{c}\text { Apparel, } 20.9 \\
\text { Footwear, } 14.0 \\
\text { Consumer } \\
\text { Electronics, } 11.6\end{array}$ & $\begin{array}{l}\chi^{2} \text {-test: } \\
\mathrm{a}^{*} ; \mathrm{b}^{\mathrm{ns}} ; \mathrm{c}^{* *}\end{array}$ \\
\hline $\begin{array}{l}\text { Share of micro (less than } 9 \text { employees)/big } \\
\text { (more than } 250 \text { employees) organisations } \\
(\%)\end{array}$ & $58 / 16.5$ & $46.9 / 15.6$ & 69.8/9.3 & $\begin{array}{l}\text { MW-U: } \\
a^{\text {ns }} ; b^{\text {ns. }} ; c^{*}\end{array}$ \\
\hline Store size $\left(\mathrm{ft}^{2}\right)[$ Mean $($ Stddev $)]$ & $3,037.6(4793.2)$ & $2,702.8(3405.7)$ & $1,155.0(1,151.7)$ & $\begin{array}{l}\text { MW-U: } \\
a^{\text {ns }} ; b^{* *} ; c^{* *} ;\end{array}$ \\
\hline Transactions per day [Mean (Stddev)] & $196.2(293.7)$ & $148.9(337.2)$ & $74.1(92.0)$ & $\begin{array}{l}\text { MW-U: } \\
a^{\text {ns }} ; b^{* * *} ; c^{*} ;\end{array}$ \\
\hline $\begin{array}{l}\text { Power of the store as a footfall generator } \\
\text { (four-point rating scale: } 1 \text {, footfall profiteer, } \\
\text {..., } 4 \text {, footfall generator) [Mean (Stddev)] }\end{array}$ & $2.6(.9)$ & $2.8(.8)$ & $2.7(.9)$ & $\begin{array}{l}\text { MW-U: } \\
a^{\text {ns. }} ; b^{\text {ns. }} ; c^{\text {nss; }}\end{array}$ \\
\hline $\begin{array}{l}\text { Attractiveness of store location within the } \\
\text { agglomeration (bipolar seven-point rating } \\
\text { scale: }-3 \text {, worst location, ..., }+3 \text {, best } \\
\text { location) [Mean (Stddev)] }\end{array}$ & $1.2(1.6)$ & $2.3(.8)$ & $1.1(1.3)$ & $a^{* * *} ; b^{n s} ; c^{* * *}$ \\
\hline $\begin{array}{l}\text { Share of store managers who are also the } \\
\text { owners of their businesses (\%) }\end{array}$ & 27.6 & 15.6 & 39.5 & $\begin{array}{l}\chi^{2} \text {-test: } \\
a^{\text {ns. }} ; b^{\text {ns; }} ; c^{*}\end{array}$ \\
\hline
\end{tabular}

Notes: a, significant difference between AGG1 and AGG2; b, significant difference between AGG1 and AGG3; c, significant difference between AGG2 and AGG3; ns, no significant difference, p>.05; *, p<.05; **, p<.01; ***, p<.001; MW-U, Mann-Whitney U Test. 


\subsection{Applied scales and measures}

We measured the latent constructs in the model through scales that researchers have used previously in inter-organisational network-like contexts, amending them according to the specific research phenomena under study here, namely competition and cooperation between stores in agglomerations (see appendix).

To measure the competition between stores, we utilised the scale that Morgan, Zou, Vorhies, and Katsikeas (2003) propose. The items measure the overall competitiveness between the stores, as well as price and promotion-based competition. For the items operationalising cooperation, we referred to the work of Prahinski and Benton (2004). These items reflect the cooperative nature of the relationships between stores, orientation towards common goals, and the effectiveness of the cooperation between stores. The respondents were presented with a seven-point rating scale for all of these items.

Finally, we chose the widely applied scales of Vorhies and Morgan (2005), Bell et al., 2010, Pauler, Trivedi, and Gauri (2009) and Venkatraman and Ramanujam (1986) to measure performance. The second-order construct of performance subsumes three latent constructs, namely customer satisfaction, market effectiveness and operational performance. The customer satisfaction sub-construct comprises the dimensions of satisfaction, loyalty, customer value delivery and customer retention. Market effectiveness refers to market share growth and sales revenue growth, new customer acquisition, and an increase in sales to existing customers. Operational performance reflects the dimensions of market share, sales and customer traffic. For all performance items, the evaluations are relative to the strongest comparable competitor outside of the agglomeration.

We measured the first potential moderating variable by asking our respondents to evaluate their location within the agglomeration with respect to its attractiveness relative to all others. The attractiveness of their store's location $\left(\mu_{1}\right)$ was measured on a bipolar, seven- 
point rating scale, -3 signifying the worst and +3 the best location within the agglomeration. In terms of our second proposed moderating variable, our respondents evaluated the power of their store $\left(\mu_{2}\right)$ on a four-point rating scale, 1 indicating that their store mostly benefitted from the footfall generated by other stores and 4 indicating that their store was a significant generator of footfall for their agglomeration (Teller \& Schnedlitz, 2012; see Table 1).

\subsection{Control variables}

We considered three control variables in our model that could influence the hypothesised effects: agglomeration size $\left(c_{1}\right)$, organisation size $\left(c_{2}\right)$ and store size $\left(c_{3}\right)$ (see Figure 2).

$c_{1}$ : The attractiveness and the type of retail and service provision that centres offer vary between agglomerations of different sizes (Huff, 1964; Reilly, 1931), and this affects the level of competition and the level of cooperation. For our first control variable, size, we used the number of retail and non-retail tenants in a centre to distinguish between different agglomeration types (Teller, 2008).

$c_{2}$ and $c_{3}$ : The attractiveness of each store to customers within a centre, and thus the contribution of each store to the overall attractiveness of a centre, also varies (Finn \& Louviere, 1996). Differences in attractiveness and thus importance have an impact on relationships, including the levels of competition and collaboration within networks (e.g. Hingley, 2005; Teller \& Reutterer, 2008). For example, key or anchor tenants that are of a larger size and represent powerful and well-known retail and service brands generate a greater footfall than the, usually smaller, less well-known tenants that benefit from that footfall rather than attracting customers independently (Teller \& Schnedlitz, 2012). We captured this difference in the importance of stores and thus their attractiveness and importance within a centre using organisation size $\left(c_{2}\right)$ and store size $\left(c_{3}\right)$. 


\subsection{Analysis}

We applied partial least squares (PLS), i.e. a variance-based structural equation modelling (SEM) approach, to test the proposed effects (Chin, 1998; Tenenhaus, Vinzi, Chatelin, \& Lauro, 2005), using the software SmartPLS (Ringle, Wende \& Becker, 2015). Our decision to use PLS was based on the work of Hair Jr, Sarstedt, Ringle, and Mena (2012) and their assessment of the use of PLS in marketing research. The PLS approach conveys a number of advantages in terms of the level of measurement and multinormality compared to covariancebased SEM approaches (Hair Jr et al., 2012). More specifically, we applied this variancebased approach because we were testing a rather complex model based on relatively small samples (Chin \& Newsted, 1999). Further, we were not attempting to test a theory but to predict the impacts of cooperation and competition on store performance, and any impacts resulting from wider agglomeration performance (Hair Jr, Ringle, \& Sarstedt, 2011). Given that the phenomenon that we are investigating here has been widely neglected, our study has a quite exploratory character and thus it was necessary to use a variance-based rather than a covariance-based SEM approach (Hair Jr et al., 2011). Finally, our data do not meet the requirement of multivariate normality (Kolmogorov-Smirnov test; $\mathrm{p}<.001$ ).

The analysis of our data and presentation of our findings are based on the guidelines suggested by Hair Jr et al. (2012) and Hair Jr, Hult, Ringle, and Sarstedt (2014). In testing the local fit of the outer, or measurement, model (i.e. the sets of constructs with the observable items standing behind them), we found that all $t$-values of the factor loadings were highly significant $(\mathrm{p}<.001)$ and all loadings exceeded the suggested size of .7 (Hulland, 1999; see appendix). This was also true for the factor loadings of the two second-order performance constructs, i.e. agglomeration and store performance. We also consider the internal consistency to be satisfactory, as all of the factors had Cronbach's alpha values exceeding .7 
(Nunnally, 1978) and the composite reliability of all factors was greater than .7 (Fornell \& Larcker, 1981).

The degree of convergent validity is acceptable, with the average variances extracted (AVEs) in the range of .5 or higher (Bagozzi \& Yi, 1988). With regard to the constructs' discriminant validity, the AVEs are all larger than the highest of the squared intercorrelations ${ }^{1}$ with the other factors in the measurement models (see Table 2). Additionally, all factor loadings on each of the assigned factors are higher than all loadings (i.e. cross-loadings) on the non-assigned factors (Chin, 1998). We can thus conclude that there is a sufficient local fit of the data.

Finally, we analysed the goodness-of-fit using the criterion proposed by Tenenhaus et al. (2005). This fit criterion represents the geometric mean of the average commonality and the average $r^{2}$ (see also Hair Jr et al., 2014). Our model provides a good goodness-of-fit of .632 , above the recommended threshold of .5 .

\footnotetext{
${ }^{1}$ We tested for factorial invariance using Henseler's (2007) distribution-free approach of multigroup comparisons. The results were non-significant across all three subsamples. For the sake of readability, we only present the aggregated intercorrelation matrix. We thank an anonymous reviewer for a helpful comment in this regard.
} 
Table 2. Convergent validity, composite reliability and discriminant validity measures

\begin{tabular}{|c|c|c|c|c|c|c|c|c|c|c|c|c|c|c|}
\hline Constructs & $\rho / \alpha$ & $\xi_{1}$ & $\xi_{2}$ & $\eta_{11}$ & $\eta_{12}$ & $\eta_{13}$ & $\eta_{21}$ & $\eta_{22}$ & $\eta_{23}$ & $\mu_{1}$ & $\mu_{2}$ & $c_{1}$ & $c_{2}$ & $c_{3}$ \\
\hline Cooperation $\left(\xi_{1}\right)$ & $.964 / .951$ & $(.870)$ & & & & & & & & & & & & \\
\hline Competition $\left(\xi_{2}\right)$ & $.928 / .898$ & .020 & $(.764)$ & & & & & & & & & & & \\
\hline Agg. perf. - Customer satisfaction $\left(\eta_{11}\right)$ & $.942 / .920$ & .052 & .115 & $(.766)$ & & & & & & & & & & \\
\hline Agg. perf. - Market effectiveness $\left(\eta_{12}\right)$ & $.964 / .951$ & .061 & .103 & .642 & $(.870)$ & & & & & & & & & \\
\hline Agg. perf. - Operational performance $\left(\eta_{13}\right)$ & $.966 / .950$ & .031 & .126 & .487 & .645 & $(.905)$ & & & & & & & & \\
\hline Store perf. - Customer satisfaction $\left(\eta_{21}\right)$ & $.902 / .866$ & .015 & .001 & .045 & .067 & .064 & $(.649)$ & & & & & & & \\
\hline Store perf. - Market effectiveness $\left(\eta_{22}\right)$ & $.920 / .885$ & .030 & .004 & .055 & .146 & .145 & .339 & $(.743)$ & & & & & & \\
\hline Store perf. - Operational performance $\left(\eta_{23}\right)$ & $.959 / .938$ & .017 & .000 & .106 & .153 & .194 & .254 & .635 & $(.887)$ & & & & & \\
\hline Attractiveness of store location $\left(\mu_{1}\right)$ & - & .042 & .050 & .021 & .047 & .022 & .022 & .049 & .067 & $(-)$ & & & & \\
\hline Power of store to generate footfall $\left(\mu_{2}\right)$ & - & .003 & .020 & .006 & .005 & .003 & .003 & .003 & .010 & .006 & $(-)$ & & & \\
\hline Agglomeration size $\left(c_{1}\right)$ & - & .001 & .104 & .123 & .114 & .139 & .000 & .002 & .002 & .008 & .007 & $(-)$ & & \\
\hline Organisation size $\left(c_{2}\right)$ & - & .000 & .005 & .001 & .004 & .008 & .000 & .031 & .023 & .016 & .038 & .003 & $(-)$ & \\
\hline Store size $\left(c_{3}\right)$ & - & .004 & .041 & .004 & .005 & .017 & .000 & .003 & .010 & .000 & .012 & .022 & .067 & $(-)$ \\
\hline
\end{tabular}




\subsection{Common method bias}

Since the study uses data based on self-reports, another important task was to consider the issue of common method bias (CMB). Here we followed a two-step approach. First we tried to avoid CMB upfront by taking into consideration the notions of Podsakoff, MacKenzie, Jeong-Yeon Lee, and Podsakoff (2003) and Podsakoff, MacKenzie, and Podsakoff (2012) when designing the questionnaire. In terms of the structure of the research instrument, we clearly separated the questions; those related to the dependent constructs were asked prior to those related to the independent ones. We applied a variety of rating scales throughout the questionnaire. Further, we did not reveal the specific purpose of our project and assured confidentiality to our respondents.

In a second step, we tested whether common method variance biased our data. In terms of testing for $\mathrm{CMB}$, it must be said that there is no single best method available (Podsakoff et al., 2012). Further, there is a critical debate on which method to use and how significantly (or not) CMB can affect data (for a critical discussion see, e.g., Richardson, Simmering, \& Sturman, 2009). We conducted a Harman's one-factor test on both datasets (Podsakoff \& Organ, 1986). To do so, we conducted exploratory factor analysis (EFA) on our variables using unrotated principal component factor analysis, constraining the number of factors to be extracted to one, that is, one general factor. We found that the one-factor solution accounted for around one third of the total variance. Further, we introduced a latent method factor (LMF) and thereby subsumed all indicators under one construct in our model according to Podsakoff et al. (2003). We estimated the model with and without the LMF and compared the results. We found that neither the factor loadings nor the path coefficients differed substantially in value, and all were significant ( $t$-value $>1.965)$ and positive. To conclude, the results from both tests suggest that common method variance is not a 
significant issue in our data, implying that CMB does not harm the interpretation of our results.

\section{Results}

We evaluated the structural models as per Chin (1998) and Cohen (1988) using the coefficients of determination $\left(r^{2}\right)$, the sizes, signs and significance of the single path coefficients $\left(\gamma_{\mathrm{n}}, \beta_{21}\right)$, and the effect sizes $\left(f^{2}\right)$. In testing the hypotheses, we took into consideration both direct and indirect effects between the latent factors. Table 3 presents the results.

\subsection{Model robustness test}

First, we evaluated the impact of our three control variables $\left(c_{1}, c_{2}\right.$, and $\left.c_{3}\right)$ on the effects in our conceptual model (see Figure 2) by following the procedure applied by Robson, Katsikeas, and Bello (2008). All but one of the impacts of the control variables $c_{1}, c_{2}$ and $c_{3}$ on agglomeration performance $\left(\eta_{1}\right)$ and store performance $\left(\eta_{2}\right)$ are insignificant and very weak $\left(f^{2}\right.$-values $\left.<<.1\right)$ (see Table 3$)$. Only the effect of the control variable $c_{1}$ (agglomeration size) on agglomeration performance is significant. Nevertheless, when comparing the structural effects as proposed in our hypotheses $\left(\beta_{21}, \gamma_{11}, \gamma_{21}, \gamma_{12}, \gamma_{22}\right)$, and including as opposed to excluding the control variables in our model, we see that the coefficients alter insignificantly in the third decimal place, while the significances of the associations do not change. Furthermore, we compared the coefficients when estimating the model with and without our control variables by following Keil et al.'s (2000) multigroup comparison approach and did not find any significant difference $(p>.05)$ between the paths of the two models. These results suggest that the three control variables do not confound the proposed relationships in our conceptual model. Moreover, we can conclude that the structural 
associations are independent of the size of the agglomeration, the size of the organisation and the size of the store.

Table 3. Direct and total structural effects

\begin{tabular}{|c|c|c|}
\hline Structural effects & \multicolumn{2}{|c|}{ Coefficient $^{(\mathrm{p} \text {-value, effect size })}$} \\
\hline $\mathrm{H}_{1}$ : Agglomeration performance $\left(\eta_{1}\right) \rightarrow$ Store performance $\left(\eta_{2}\right)$ & $\beta_{21}$ & $.460^{* * *(\mathrm{~s})}$ \\
\hline $\mathrm{H}_{2}$ : Cooperation $\left(\xi_{1}\right) \rightarrow$ Agglomeration performance $\left(\eta_{1}\right)$ & $\gamma_{11}$ & $.217^{* * *(\mathrm{~m})}$ \\
\hline $\mathrm{H}_{3}:$ Cooperation $\left(\xi_{1}\right) \rightarrow$ Store performance $\left(\eta_{2}\right)$ & $\gamma_{21}$ & $.078^{\mathrm{ns}(\mathrm{w})}$ \\
\hline $\mathrm{H}_{4}:$ Competition $\left(\xi_{2}\right) \rightarrow$ Agglomeration performance $\left(\eta_{1}\right)$ & $\gamma_{12}$ & $.231^{* * *(\mathrm{~m})}$ \\
\hline $\mathrm{H}_{5}:$ Competition $\left(\xi_{2}\right) \rightarrow$ Store performance $\left(\eta_{2}\right)$ & $\gamma_{22}$ & $-.138^{*(w)}$ \\
\hline Total effects (direct plus indirect effects) & \multicolumn{2}{|c|}{ Coefficient } \\
\hline $\mathrm{H}_{2}:$ Cooperation $\left(\xi_{1}\right) \rightarrow$ Store performance $\left(\eta_{2}\right)$ & $\begin{array}{c}\gamma_{21}+\gamma_{11} * \beta_{21} \\
\left.\text { (Mediator, } \eta_{1}\right)\end{array}$ & $.178^{* *(m)}$ \\
\hline $\mathrm{H}_{5}:$ Competition $\left(\xi_{2}\right) \rightarrow$ Store performance $\left(\eta_{2}\right)$ & $\begin{array}{c}\gamma_{22}+\gamma_{21} * \beta_{21} \\
\left.\text { (Mediator, } \eta_{1}\right)\end{array}$ & $-.032^{\mathrm{ns}(\mathrm{w})}$ \\
\hline \multicolumn{3}{|l|}{ Moderating effects } \\
\hline $\mathrm{H}_{1 \mathrm{a}}$ : Interaction term $\left(\eta_{1} * \mu_{1}\right) \rightarrow$ Store performance $\left(\eta_{2}\right)$ & \multicolumn{2}{|c|}{$.042^{\mathrm{ns}(\mathrm{w})}$} \\
\hline $\mathrm{H}_{1 \mathrm{~b}}$ : Interaction term $\left(\eta_{1} * \mu_{2}\right) \rightarrow$ Store performance $\left(\eta_{2}\right)$ & \multicolumn{2}{|c|}{$.046^{\mathrm{ns}(w)}$} \\
\hline Control variables & \multicolumn{2}{|c|}{ Coefficient } \\
\hline Agglomeration size $\left(c_{1}\right) \rightarrow$ Agglomeration performance $\left(\eta_{1}\right)$ & \multicolumn{2}{|c|}{$-.312^{* * * *(\mathrm{~m})}$} \\
\hline Agglomeration size $\left(c_{1}\right) \rightarrow$ Store performance $\left(\eta_{2}\right)$ & \multicolumn{2}{|c|}{$.100^{\mathrm{ns}(\mathrm{w})}$} \\
\hline Organisation size $\left(c_{2}\right) \rightarrow$ Agglomeration performance $\left(\eta_{1}\right)$ & \multicolumn{2}{|c|}{$.036^{\mathrm{ns}(\mathrm{w})}$} \\
\hline Organisation size $\left(c_{2}\right) \rightarrow$ Store performance $\left(\eta_{2}\right)$ & \multicolumn{2}{|c|}{$.086^{\mathrm{ns}(\mathrm{w})}$} \\
\hline Store size $\left(c_{3}\right) \rightarrow$ Agglomeration performance $\left(\eta_{1}\right)$ & \multicolumn{2}{|c|}{$.002^{\mathrm{ns}(\mathrm{w})}$} \\
\hline Store size $\left(c_{3}\right) \rightarrow$ Store performance $\left(\eta_{2}\right)$ & \multicolumn{2}{|c|}{$.034^{\mathrm{ns}(\mathrm{w})}$} \\
\hline \multicolumn{3}{|c|}{$\begin{array}{l}\text { Notes: }{ }^{*}, t \text {-values significant at } p<.05 \text { level }(* *, p<.01 ; * * *, p<.001) ; t \text {-values calculated by } \\
\text { applying a bootstrapping procedure with } 1,000 \text { subsamples (Chin, 1998); (w), weak effect } \\
\left(f^{2} \text {-value } \sim .02\right),(\mathrm{m}) \text {, moderate effect }\left(f^{2} \text {-value } \sim .15\right) ; \mathrm{s} \text {, strong effect }\left(f^{2} \text {-value } \sim .35\right) ; \\
\text { coefficients of determination, } r_{\eta_{1}}^{2}, .260 ; r_{\eta_{2}}^{2}, .207 .\end{array}$} \\
\hline
\end{tabular}




\subsection{Structural effect and hypothesis testing}

Hypothesis 1: Our results clearly reveal a spill-over effect from the agglomeration to the store performance. This agglomeration effect proves to be significant and strong $\left(\beta_{21}, .460\right)$. This clearly suggests that the first alternative hypothesis is supported.

Hypotheses $1 a$ and $b$ : To test for moderation we utilised the product indicator approach based on the notions of Busemeyer and Jones (1983) and Kenny and Judd (1984). This approach requires the calculation of product terms using the indicators of the predicting variable (in our case agglomeration performance $\left.\left(\eta_{1}\right)\right)$ and the moderator variables $\left(\mu_{1}\right.$ and $\left.\mu_{2}\right)$ (Henseler \& Chin, 2010). The product terms are then included as (latent) interaction terms that represent the moderating effects in the structural model. The effects of the interaction terms on the performance spill-over effect $\left(\mathrm{H}_{1}\right)$ in the model measure the significance and the size of a moderating effects.

The results of the moderation test reveal that the interaction effects - in both cases are very weak and not significant. Consequently, neither the attractiveness of the store's location within the agglomeration $\left(\mu_{1}, .042 ; p, .745 ; f^{2}, .025\right)$ nor the power of the store to generate footfall for the agglomeration $\left(\mu_{2}, .046 ; p, .740 ; f^{2}, .001\right)$ has a moderating effect. We thus conclude that neither the attractiveness of the intra-agglomeration location nor the power of the store affects the performance spill-over effect $\left(\mathrm{H}_{1}\right)$. We thus cannot confirm either $\mathrm{H}_{1 \mathrm{a}}$ or $\mathrm{H}_{1 \mathrm{~b}}$.

Hypotheses 2 and 3: Looking at the impact of cooperation on agglomeration performance we see a significant and medium-sized effect $\left(\gamma_{11}, .217\right)$, which supports our second hypothesis. The testing of hypothesis 3 requires a more in-depth analysis of the results. The direct effect between cooperation and store performance is insignificant and weak $\left(\gamma_{21}, .078\right)$, which leads to the rejection of the third hypothesis as it was set out in our 
conceptual model. Nevertheless, we identify significant and medium-sized indirect $\left(\gamma_{11} * \beta_{21}\right.$, $.099)$ and total $\left(\gamma_{21}+\gamma_{11} * \beta_{21}, .177\right)$ effects. This indicates a mediation of the construct agglomeration performance. We carried out a mediation test based on the four-step procedure of Baron and Kenny (1986). Sobel's test (1982) reveals a (Sobel's) z-value of 3.397, meaning that the indirect effects are significantly different from zero $(\mathrm{p}<.001)$. We can thus conclude that the relationship between cooperation and store performance is fully mediated by agglomeration performance (Zhao, Lynch Jr, \& Chen, 2010). Additionally, we determined the size and strength of the mediating effects using the measure "variance accounted for" (VAF), based on Shrout and Bolger's (2002) formula. The VAF value is .540, which suggests that the mediating power is rather strong.

Hypotheses 4 and 5: The next set of tests focuses on the impact of competition on our dependent variables. The effect on agglomeration performance is comparable to that of cooperation, in that it is significant and of medium size $\left(\gamma_{12}, .231\right)$. Thus, hypothesis 4 is supported. The test of our fifth and last hypothesis reveals even more interesting results. As proposed, competition affects store performance negatively and significantly, yet the effect size is comparably weak $\left(\gamma_{22},-.138\right)$. Therefore, the hypothesis 5 is supported as well. Taking a closer look at the total effect, we find this to be insignificant and very weak $\left(\gamma_{22}+\gamma_{12} * \beta_{21}\right.$, .032). The indirect effect is contrary to the direct one, being positive and significant as well $\left(\gamma_{12} * \beta_{21}, .106\right)$. These results again indicate a mediating role played by agglomeration performance. Baron and Kenny's procedure (1986) and the (Sobel's) z-value of 3.340 show that the indirect effect is significantly different from zero. The VAF value is .416 and thus indicates strong mediation. Since the indirect effect is significant and different from zero and the direct effect is significant and negative, we can conclude that agglomeration performance has a competitive mediation (Zhao et al., 2010) effect on the relationship between 
competition and store performance. As such, the negative direct effect is outweighed by the positive indirect (mediated) effect.

\section{Implications for theory}

\subsection{Performance spill over and cooperating for the greater good}

The first contribution of this paper is the demonstration that cooperation between stores within agglomerations positively influences the performance of those agglomerations, independent of their type and size. In line with the findings of Teller and Schnedlitz (2012), this conclusion also holds for stores and parent organisations of different sizes as well as stores in different locations and with different capacities to generate footfall within agglomerations. In particular, the latter finding contributes to the understanding of the role of big anchor stores within agglomerations (e.g., Finn \& Louviere, 1996), such that we can conclude that all stores benefit to the same degree from a performance spill-over effect. This also provides support for the literature on the topic of place management and marketing, which promotes the encouragement and management of cooperation between place actors in general, and stores in particular, to enhance the attractiveness and performance of places such as town centres and shopping centres (Howard, 1997; Teller \& Elms, 2012; Warnaby, Bennison, Davies, \& Hughes, 2004). The results show that cooperation does not affect the performance of stores directly but rather indirectly through agglomeration performance, which then spills over onto store performance. As such, our findings complement Brass et al.'s (2004) notion that organisations (should) collaborate in networks such as agglomerations, e.g. in terms of operational marketing matters and in the purchasing of assets to support these matters, in order to first strengthen the network (agglomeration) and then benefit from that strengthened network. Overall, our results support Dyer and Singh's (1998) view on the benefits generated through collaboration in business networks, and thus highlight the potential of cooperation between stores. 


\subsection{Competition might be a good thing after all}

The second major contribution relates to what at first seems to be the paradoxical role of competition between stores in an agglomeration. On the one hand, and as expected, competition has a negative direct impact on the performance of stores. However, on the other hand, competition shows an even stronger positive effect on the agglomeration's performance. In total, the negative effect of competition is neutralised by the positive spill over from agglomeration to store performance. This finding is in line with the customer view on competition in agglomerations in the work of, for example, Yiu and $\mathrm{Xu}$ (2012) and Oppewal and Holyoake (2004). The identification of any spill-over effects reflects the benefits of agglomeration-level synergies for the individual store (Chetty \& Wilson, 2003). Our findings suggest that the effects of agglomeration performance on store performance are positive. Equally, however, in other circumstances the fact that stores are so closely bounded to their environments within agglomerations could leave them vulnerable to weaknesses and problems at the agglomeration level (see also Wilkinson \& Young, 2002).

\subsection{Coopetition in agglomerations}

A wider implication of the identification of a spill-over effect from the agglomeration performance to the store performance is that it demonstrates the complex interplay between cooperation and competition and their similar, positive contributions to the agglomeration and store performance in our empirical settings.

It thus suggests the importance of managing the balance of these two interaction logics through the notion of coopetition (Bengtsson \& Kock, 2000; Gnyawali \& Park, 2011). Based on the notions of Peng, Pike, Yang, and Roos (2012), we consider coopetition in our context as cooperation with competition. The significant positive intercorrelation between cooperation and competition in our empirical results confirms the interplay between the two 
concepts as suggested by Chen (2008) and reveals the coopetitive context within horizontal inter-organisational (service delivery) networks. As Brandenburger and Nalebuff (1998) suggest, coopetition capability represents an opportunity to increase the competitiveness and performance of the agglomeration (Gnyawali \& Park, 2011), but not one without challenges for the management resulting from the diametrically opposed nature of these two logics of interaction (Bengtsson \& Kock, 2000; Clarke-Hill et al., 2003). Consequently, and based on the notions of Dyer and Singh (1998), overcoming the negative attitudes towards competition - and its possible negative consequences - and seeking collaboration with competitors within the network refers to an investment in inter-firm relation-specific assets by store managers that can lead to a competitive advantage at both an agglomeration and a store level.

\section{Implications for practice}

The results of our study have clear managerial implications. First they provide clear evidence of the effects of competition and cooperation on store performance, including those that result from their impact on the wider agglomeration performance. This insight into the mechanisms and effects of competitive and cooperative relationships between stores in agglomerations is of inherent relevance to the management of the retail stores and also to the managers of the agglomerations (in our case the shopping centres). We highlight three aspects here, taking into consideration the views of both store and agglomeration managers.

A call for more cooperation: The conclusions herein should encourage managers of stores and those working in the stores' parent organisations to invest in collaborative measures, including those related to marketing and operations, in order to increase the attractiveness, efficiency and effectiveness of their agglomerations. Such investments will offer returns in the form of improved store performance. For agglomeration managers our results provide clear evidence of the benefits of collaborative measures between stores and a convincing rationale for those promoting them. This is vital since motivating store managers 
to collaborate is a particularly challenging task given the high operative pressure store managers are confronted with and the difficulties they face in making (time and financial) resources available, for example for cooperative marketing initiatives.

The positive impact of competition in agglomerations: Our findings suggest that competition has a significant and direct positive effect on agglomeration performance and a non-significant and thus neutral effect on store performance. Based on that, agglomeration managers should try to increase the level of direct competition between stores when planning tenant mix, other things being equal. This could include proactively encouraging new retail and service organisations to locate their stores in an agglomeration even if this could represent a challenge for existing stores. Managers might also explain the beneficial role of competition to the existing store managers, in order to avoid the fostering of unduly negative attitudes or resistance towards the new stores.

Coopetition - a new mind-set in agglomerations: Another practical implication of our study is that store managers in agglomerations should adopt, and agglomeration managers promote, coopetitive thinking as well as measures. The distinction between friends (collaborators) and foes (competitors) in terms of other stores and organisations appears to be inappropriate in such service delivery networks. Managers need to understand that all stores need to both cooperate and compete, and thus need to act according to both logics of interaction, for the greater good of their common agglomeration. The capability to effectively manage and live coopetitively can result in a sustainable competitive advantage for an agglomeration.

\section{Limitations and future research}

As with all research, this study has some limitations. Despite the fact that the context-specific characteristics of the inner-city agglomeration in this empirical study are arguably typical of 
those in many developed urban regions, interpretations of the data must take that context into account. Future studies in other contexts, for example suburban and extra-urban shopping malls or retail parks, could help to confirm our findings. It would also be of interest to consider other types of geographically bounded service delivery networks, such as restaurants, bars and other visitor attractions in tourist destinations.

Our empirical approach features the views of the store managers since we believe that they are the right informants for the phenomenon under investigation. Further research could also consider the perspectives of other stakeholder groups in agglomerations, such as the regional managers of retail and service organisations, as well as town centre, high street and shopping centre managers.

In our research we have identified a strong spill-over effect from agglomeration to store performance. Further research could also test the reciprocal nature of this effect and look for other possible moderating effects. This would shed light on the question of who is benefitting more from whom: the agglomeration from the store or the stores from the agglomerations.

Finally, the focus of our research is on the effect of cooperation and competition on performance. As a result, we do not consider managerial processes - at a store/node or agglomeration/network level - that result in those effects. Teller and Alexander (2014) see the store manager as key to unlocking potential and consequently building up a competitive advantage for the network and its nodes. More specifically, they suggest that it is his/her willingness and ability to collaborate and thereby cross boundaries to other stores, other organisations and the network management that is important. This is an important topic for further research. 
Further research could also look into choice behaviour with respect to whether and how store managers should collaborate or compete with other managers in the networks, and the related benefits for store managers, for example by taking a game theory view (e.g., Parkhe, 1993). This could also take into consideration the views of agglomeration managers and their influence on coopetitive intensity. Such research could make more visible the motives and constraints of both store and agglomeration managers when it comes to behaving in a coopetitive manner in service delivery networks. 


\section{Appendix}

\begin{tabular}{|c|c|c|c|}
\hline $\begin{array}{l}\text { Construct (scale, source) } \\
\text { Indicator }\end{array}$ & $\mu(\sigma)$ & $\begin{array}{l}\text { Factor loading } \\
(t \text {-values })\end{array}$ & $\begin{array}{c}\text { Reliability, } \\
\text { validity measures }\end{array}$ \\
\hline \multicolumn{4}{|l|}{$\xi_{1}$, Competition (seven-point rating scale, 0 , fully disagree, 6 , fully agree; Morgan et al., 2003) } \\
\hline$x_{11}$, Competition between stores in $[\ldots]$ is cut-throat. & $3.3(1.6)$ & $.841(18.136)$ & \multirow{4}{*}{$\begin{array}{c}\alpha, .898 \\
\rho, .928 \\
A V E, .764\end{array}$} \\
\hline$x_{12}$, There are many "promotion" wars in $[\ldots]$ to get customers into stores. & $3.4(1.6)$ & $.877(22.237)$ & \\
\hline$x_{13}$, Price competition between stores is a hallmark of $[\ldots]$ & $2.6(1.6)$ & $.897(21.831)$ & \\
\hline$x_{14}$, One hears of new competitive moves by stores within [...] very frequently. & $2.5(1.8)$ & $.880(23.148)$ & \\
\hline \multicolumn{4}{|c|}{$\xi_{2}$, Cooperation (seven-point rating scale, 0 , fully disagree, 6 , fully agree; Prahinski \& Benton, 2004) } \\
\hline $\begin{array}{l}x_{21} \text {, The relationship between stores is better described as a cooperative effort than an } \\
\text { adversarial one. }\end{array}$ & $1.8(1.7)$ & $.905(20.394)$ & \multirow{4}{*}{$\begin{array}{c}\alpha, .951 \\
\rho, .964 \\
A V E, .870\end{array}$} \\
\hline$x_{22}$, Stores in this shopping street work together to achieve their common goals. & $2.3(1.7)$ & $.935(24.068)$ & \\
\hline$x_{23}$, The cooperation between stores in $[\ldots]$ is effective. & $2.2(1.7)$ & $.953(23.860)$ & \\
\hline$x_{24}$, The stores in $[\ldots]$ are concerned about the success of single stores. & $2.1(1.7)$ & $.936(24.134)$ & \\
\hline \multicolumn{2}{|c|}{$\begin{array}{l}\eta_{1}, \text { Network performance (bipolar seven-point rating scale; }-3, \text { significantly worse, }+3, \\
\text { significantly better than the strongest competing network) }\end{array}$} & \multicolumn{2}{|c|}{ Second-order construct } \\
\hline \multicolumn{4}{|c|}{$\eta_{11}$, Customer satisfaction related to [...] (Vorhies \& Morgan, 2005, Bell, Mengüç \& Widing, 2010) } \\
\hline$y_{112}$, Customer satisfaction & $1.6(1.4)$ & $.872(15.277)$ & \multirow{5}{*}{$\begin{array}{c}\alpha, .925 \\
\rho, .942 \\
A V E, .766\end{array}$} \\
\hline$y_{113}$, Customer loyalty & $1.7(1.2)$ & $.880(15.043)$ & \\
\hline$y_{114}$, Delivering superior value to your customers & $1.6(1.2)$ & $.854(13.616)$ & \\
\hline$y_{115}$, Delivering what your customers want & $1.5(1.5)$ & $.883(16.585)$ & \\
\hline$y_{116}$, Retaining valued customers & $1.6(1.5)$ & $.887(16.059)$ & \\
\hline \multicolumn{4}{|l|}{$\eta_{12}$, Market effectiveness of [...] (Vorhies \& Morgan, 2005, Bell, Mengüç \& Widing, 2010) } \\
\hline$y_{121}$, Market share growth relative to competitors & $1.2(1.4)$ & $.941(19.887)$ & \multirow{4}{*}{$\begin{array}{c}\alpha, .951 \\
\rho, .964 \\
A V E, .870\end{array}$} \\
\hline$y_{122}$, Growth in sales revenue & $1.2(1.4)$ & $.946(20.470)$ & \\
\hline$y_{123}$, Acquiring new customers & $1.4(1.5)$ & $.933(18.368)$ & \\
\hline$y_{124}$, Increasing sales to existing customers & $1.3(1.3)$ & $.909(17.654)$ & \\
\hline
\end{tabular}


$\eta_{13}$, Operational performance of [...] (Venkatraman \& Ramanujam, 1986; Pauler et al., 2009)

$y_{131}$, Market share

$y_{132}$, Sales

$\eta_{2}$, Store performance (bipolar seven-point rating scale; -3 , significantly worse, +3 ,

significantly better than the strongest competing store (outside the network))

$\eta_{21}$, Customer satisfaction related to [...] (Vorhies \& Morgan, 2005; Bell, Mengüç \& Widing, 2010)

\section{$y_{212}$, Customer satisfaction}

$y_{213}$, Customer loyalty

$y_{214}$, Delivering superior value to your customers

$y_{215}$, Delivering what your customers want

$y_{216}$, Retaining valued customers

$\eta_{22}$, Market effectiveness of [...] (Vorhies \& Morgan, 2005; Bell, Mengüç \& Widing, 2010)

$y_{221}$, Market share growth relative to competitors

$y_{222}$, Growth in sales revenue

$y_{223}$, Acquiring new customers

$y_{224}$, Increasing sales to existing customers

$\eta_{23}$, Operational performance of $[\ldots]$

Venkatraman \& Ramanujam, 1986; Pauler et al., 2009) $y_{231}$, Market share

$y_{232}$, Sales

$y_{233}$, Customer traffic
$1.2(1.4)$

$1.2(1.5)$

$1.4(1.6)$
$2.0(1.0)$

$1.8(1.1)$

$1.9(1.1)$

$1.7(1.2)$

$1.9(1.1)$
$.961(19.575)$

$.947(20.483)$

$.946(18.904)$

Second-order construct

$.778(7.243)$

$.806(9.418)$

$.833(10.223)$

$.789(10.545)$

$.821(11.104)$

$1.1(1.3) \quad .899(17.561)$

$1.1(1.3) \quad .910(18.036)$

$1.4(1.3) \quad .849(12.316)$

$1.2(1.2) \quad .784(11.364)$

Notes: $\mu$, mean value; $\sigma$, standard deviation; $\alpha$, Cronbach's alpha; $\rho$, composite reliability; $A V E$, average variance extracted. 


\section{References}

Arentze, T. A., Oppewal, H., \& Timmermans, H. J. P. (2005). A multipurpose shopping trip model to assess retail agglomeration effects. Journal of Marketing Research, 42, 109-115.

Bagozzi, R. P., \& Yi, Y. (1988). On the evaluation of structural equation models. Journal of the Academy of Marketing Science, 16, 74-94.

Balakrishnan, M. S. (2009). Strategic branding of destinations: A framework. European Journal of Marketing, 43, 611-629.

Barney, J. (1991). Firm resources and sustained competitive advantage. Journal of Management, $17,99-120$.

Baron, R. M., \& Kenny, D. A. (1986). The moderator-mediator variable distinction in social psychological research: Conceptual, strategic, and statistical considerations. Journal of Personality and Social Psychology, 51, 1173-1182.

Bell, S. J., Mengüç, B., \& Widing II, R. E. (2010). Salesperson learning, organizational learning, and retail store performance. Journal of the Academy of Marketing Science, 38, 187-201.

Bengtsson, M., \& Kock, S. (1999). Cooperation and competition in relationships between competitors in business networks. Journal of Business \& Industrial Marketing, 14, 178-190.

Bengtsson, M., \& Kock, S. (2000). "Coopetition" in business networks - to cooperate and compete simultaneously. Industrial Marketing Management, 29, 411-427.

Brandenburger, A. M., \& Nalebuff, B. J. (1998). Co-opetition. New York: Currency Doubleday. Brass, D. J., Galaskiewicz, J., Greve, H. R., \& Tsai, W. (2004). Taking stock of networks and organizations: A multilevel perspective. Academy of Management Journal, 47, 795-817.

Busemeyer, J. R., \& Jones, L. E. (1983). Analysis of multiplicative combination rules when the causal variables are measured with error. Psychological Bulletin, 93, 549-562. 
Campell, D. T. (1955). The informant in quantitative research. American Journal of Sociology, $60,339-342$.

Chen, M. (2008). Reconceptualizing the competition-cooperation relationship. Journal of Management Inquiry, 17, 288-304.

Chetty, S. K., \& Wilson, H. I. M. (2003). Collaborating with competitors to acquire resources. International Business Review, 12, 61-81.

Chin, W. W. (1998). The partial least squares approach to structural equation modelling. In G. A. Marcoulides (Ed.), Modern methods for business research (pp. 295-336). Hillsdale, NJ: Lawrence Erlbaum Associates.

Chin, W. W., \& Newsted, P. R. (1999). Structural equation modelling: Analysis with small samples using partial least squares. In R. H. Hoyle (Ed.), Statistical strategies for small sample research (pp. 307-341). Thousand Oaks, CA: Sage.

Clarke-Hill, C., Li, H., \& Davies, B. (2003). The paradox of co-operation and competition in strategic alliances: Towards a multi-paradigm approach. Management Research News, 26, $1-20$.

Cohen, J. (1988). Statistical power analysis for the behavioral sciences. Hillsdale, NJ: Lawrence Erlbaum Associates.

Das, T. K., \& Bing-Sheng Teng. (2000). Instabilities of strategic alliances: An internal tensions perspective. Organization Science, 11, 77-101.

Dennis, C., Marsland, D., \& Newman, A. (2005). Objects of desire: Consumer behaviour in shopping centre choices. Hampshire/New York: Palgrave MacMillan.

Dillman, D. A., Smyth, J. D., \& Christian, L. M. (2009). Internet, mail, and mixed-mode surveys: The tailored design method. Hoboken, NJ: John Wiley and Son. 
Dyer, J. H., \& Singh, H. (1998). The relational view: Cooperative strategy and sources of interorganizational competitive advantage. Academy of Management Review, 23, 660-679.

Field, K. (2006). War of two worlds. Chain Store Age, 82, 134.

Finn, A., \& Louviere, J. J. (1996). Shopping center image, consideration, and choice: Anchor store contribution. Journal of Business Research, 35, 241-251.

Fornell, C., \& Larcker, D. F. (1981). Evaluating structural equation models with unobservable variables and measurement error. Journal of Marketing Research, 18, 39-40.

Gnyawali, D. R., \& Park, B. (2011). Co-opetition between giants: Collaboration with competitors for technological innovation. Research Policy, 40, 650-663.

Grandori, A., \& Soda, G. (1995). Inter-firm networks: Antecedents, mechanisms and forms. Organization Studies, 16, 183-214.

Grant, R. M. (1991). The resource-based theory of competitive advantage: Implications for strategy formulation. California Management Review, 33, 114-135.

Guy, C. (2007). Planning for retail development. A critical view of the British experience. London, New York: Routledge.

Hair Jr, J. F., Hult, G. T. M., Ringle, C. M., \& Sarstedt, M. (2014). A primer on partial least squares structural equation modeling (PLS-SEM). Thousand Oaks, CA: Sage.

Hair Jr, J. F., Ringle, C. M., \& Sarstedt, M. (2011). PLS-SEM: Indeed a silver bullet. Journal of Marketing Theory and Practice, 19, 139-151.

Hair Jr, J. F., Sarstedt, M., Ringle, C. M., \& Mena, J. A. (2012). An assessment of the use of partial least squares structural equation modeling in marketing research. Journal of the Academy of Marketing Science, 40, 414-433. 
Håkansson, H., \& Ford, D. (2002). How should companies interact in business networks? Journal of Business Research, 55, 133-139.

Haytko, D. L. (2004). It's all at the mall: Exploring adolescent girls' experiences. Journal of Retailing, 80, 67-83.

Henseler, J. (2007). A new and simple approach to multi-group analysis in partial least squares path modeling. In H. Martens, \& T. Naes (Eds.), Causalities explored by indirect observation: Proceedings of the $5^{\text {th }}$ International Symposium on PLS and Related Methods (PLS’07) (pp. 195-218). Oslo: 5th International Symposium on PLS and Related Methods.

Henseler, J., \& Chin, W. W. (2010). A comparison of approaches for the analysis of interaction effects between latent variables using partial least squares path modeling. Structural Equation Modeling: A Multidisciplinary Journal, 17, 82-109.

Hingley, M. K. (2005). Power to all our friends? Living with imbalance in supplier-retailer relationships. Industrial Marketing Management, 34, 848-858.

Howard, E. (1997). The management of shopping centres: Conflict or collaboration? International Review of Retail, Distribution \& Consumer Research, 7, 263-285.

Huff, D. L. (1964). Defining and estimating a trading area. Journal of Marketing, 28, 34-38. Hulland, J. (1999). Use of partial least squares (PLS) in strategic management research: A review of four recent studies. Strategic Management Journal, 20, 195-204.

Kalen, P. (1966). Local cooperation between the independent merchants in Sweden: 'Combined department stores'. Journal of Retailing, 42, 26.

Keil, M., Tan, B. C. Y., Wei, K., Saarinen, T., Tuunainen, V., \& Wassenaar, A. (2000). A crosscultural study on escalation of commitment behavior in software projects. MIS Quarterly, 24, 299-325. 
Kenny, D. A., \& Judd, C. M. (1984). Estimating the nonlinear and interactive effects of latent variables. Psychological Bulletin, 96, 201-210.

Knoben, J., \& Oerlemans, L. A. G. (2006). Proximity and inter-organizational collaboration: A literature review. International Journal of Management Reviews, 8, 71-89.

Konopa, L. J., \& Zallocco, R. L. (1981). A study of conflict between shopping center managers and retailers within regional shopping centers. Journal of the Academy of Marketing Science, 9, 274-287.

Kumar, N., Stern, L. W., \& Anderson, J. C. (1993). Conducting interorganizational research using key informants. Academy of Management Journal, 36, 1633-1651.

Lavie, D. (2006). The competitive advantage of interconnected firms: An extension of the resource-based view. Academy of Management Review, 31, 638-658.

Lindgreen, A., Vanhamme, J., van Raaij, E. M., \& Johnston, W. J. (2013). Go configure: The mix of purchasing practises to choose for your supply base. California Management Review, $55,72-96$.

Lusch, R. F., \& Serpkenci, R. R. (1990). Personal differences, job tension, job outcomes, and store performance: A study of retail store managers. Journal of Marketing, 54, 85-101.

Mintel. (2014). E-commerce around Europe: Reviewing 2013. London: Mintel.

Möller, K., \& Rajala, A. (2007). Rise of strategic nets - new modes of value creation. Industrial Marketing Management, 36, 895-908.

Morgan, N. A., Zou, S., Vorhies, D. W., \& Katsikeas, C. S. (2003). Experiential and informational knowledge, architectural marketing capabilities, and the adaptive performance of export ventures: A cross-national study. Decision Sciences, 34, 287. 
Nevin, J. R., \& Houston, M. J. (1980). Image as a component of attraction to intraurban shopping areas. Journal of Retailing, 56, 77-93.

Nunnally, J. C. (1978). Psychometric theory. New York: McGraw-Hill.

Oh, L., Teo, H., \& Sambamurthy, V. (2012). The effects of retail channel integration through the use of information technologies on firm performance. Journal of Operations Management, $30,368-381$.

Oppewal, H., \& Holyoake, B. (2004). Bundling and retail agglomeration effects on shopping behavior. Journal of Retailing and Consumer Services, 11, 61-74.

Parkhe, A. (1993). Strategic alliance structuring: A game theoretic and transaction cost examination of interfirm cooperation. Academy of Management Journal, 36, 794-829.

Pauler, G., Trivedi, M., \& Gauri, D. K. (2009). Assessing store performance models. European Journal of Operational Research, 197, 349-359.

Peng, T. A., Pike, S., Yang, J. C., \& Roos, G. (2012). Is cooperation with competitors a good idea? An example in practice. British Journal of Management, 23, 532-560.

Peteraf, M. A. (1993). The cornerstones of competitive advantage: A resource-based view. Strategic Management Journal, 14, 179-191.

Piercy, N. F. (2009). Strategic relationships between boundary-spanning functions: Aligning customer relationship management with supplier relationship management. Industrial Marketing Management, 38, 857-864.

Podsakoff, P. M., MacKenzie, S. B., Jeong-Yeon Lee, \& Podsakoff, N. P. (2003). Common method biases in behavioral research: A critical review of the literature and recommended remedies. Journal of Applied Psychology, 88, 879-903. 
Podsakoff, P. M., MacKenzie, S. B., \& Podsakoff, N. P. (2012). Sources of method bias in social science research and recommendations on how to control it. Annual Review of Psychology, $63,539-569$.

Podsakoff, P. M., \& Organ, D. W. (1986). Self-reports in organizational research: Problems and prospects. Journal of Management, 12, 531-544.

Prahinski, C., \& Benton, W. C. (2004). Supplier evaluations: Communication strategies to improve supplier performance. Journal of Operations Management, 22, 39-62.

Reilly, W. J. (1931). The law of retail gravitation. New York: published by the author.

Richardson, H. A., Simmering, M. J., \& Sturman, M. C. (2009). A tale of three perspectives: Examining post hoc statistical techniques for detection and correction of common method variance. Organizational Research Methods, 12, 762-800.

Ringle, C.M., Wende, S. and Becker, J. (2015), SmartPLS 3 (http://www.smartpls.com), SmartPLS GmbH, Boenningstedt.

Robson, M. J., Katsikeas, C. S., \& Bello, D. C. (2008). Drivers and performance outcomes of trust in international strategic alliances: The role of organizational complexity. Organization Science, 19, 647-665.

Schoenherr, T., Modi, S. B., Benton, W. C., Carter, C. R., Choi, T. Y., Larson, P. D., Leenders, M. R., Mabert, V. A., Narasimhan, R., \& Wagner, S. M. (2012). Research opportunities in purchasing and supply management. International Journal of Production Research, 50, 4556-4579.

Sheth, J. N., Sharma, A., \& Iyer, G. R. (2009). Why integrating purchasing with marketing is both inevitable and beneficial. Industrial Marketing Management, 38, 865-871. 
Shrout, P. E., \& Bolger, N. (2002). Mediation in experimental and nonexperimental studies: New procedures and recommendations. Psychological Methods, 7, 422-445.

Sobel, M. E. (1982). Asymptotic intervals for indirect effects in structural equations models. In S. Leinhart (Ed.), Sociological Methodology (pp. 290-312). San Francisco: Jossey-Bass.

Swaminathan, V., \& Moorman, C. (2009). Marketing alliances, firm networks, and firm value creation. Journal of Marketing, 73, 52-69.

Tax, S. S., McCutcheon, D., \& Wilkinson, I. F. (2013). The service delivery network (SDN): A customer-centric perspective of the customer journey. Journal of Service Research, 16, 454470.

Teller, C. (2008). Shopping streets versus shopping malls - determinants of agglomeration format attractiveness from the consumers' point of view. International Review of Retail, Distribution \& Consumer Research, 18, 381-403.

Teller, C., \& Alexander, A. (2014). Store managers - the seismographs in shopping centres. European Journal of Marketing, 48, 2127-2152.

Teller, C., \& Elms, J. R. (2012). Urban place marketing and retail agglomeration customers. Journal of Marketing Management, 28, 546-567.

Teller, C., \& Reutterer, T. (2008). The evolving concept of retail attractiveness: What makes retail agglomerations attractive when customers shop at them? Journal of Retailing and Consumer Services, 15, 127-143.

Teller, C., \& Schnedlitz, P. (2012). Drivers of agglomeration effects in retailing: The shopping mall tenant's perspective. Journal of Marketing Management, 28, 1043-1061.

Tenenhaus, M., Vinzi, V. E., Chatelin, Y. M., \& Lauro, C. (2005). PLS path modeling. Computational Statistics \& Data Analysis, 48, 159-205. 
Venkatraman, N., \& Ramanujam, V. (1986). Measurement of business performance in strategy research: A comparison of approaches. Academy of Management Review, 11, 801-814.

Vorhies, D. W., \& Morgan, N. A. (2005). Benchmarking marketing capabilities for sustainable competitive advantage. Journal of Marketing, 69, 80-94.

Wagner, S. M., \& Kemmerling, R. (2010). Handling nonresponse in logistics research. Journal of Business Logistics, 31, 357-381.

Warnaby, G., Alexander, A., \& Medway, D. (1998). Town centre management in the UK: A review, synthesis and research agenda. International Review of Retail, Distribution \& Consumer Research, 8, 15-31.

Warnaby, G., Bennison, D., Davies, B. J., \& Hughes, H. (2004). People and partnerships: Marketing urban retailing. International Journal of Retail \& Distribution Management, 32, 545-556.

Wernerfelt, B. (1984). A resource-based view of the firm. Strategic Management Journal, 5, 171-180.

Wilkinson, I., \& Young, L. (2002). On cooperating: Firms, relations and networks. Journal of Business Research, 55, 123-132.

Yiu, C. Y., \& Xu, S. Y. S. (2012). A tenant-mix model for shopping malls. European Journal of Marketing, 46, 524-541.

Zaheer, A., \& Bell, G. G. (2005). Benefiting from network position: Firm capabilities, structural holes, and performance. Strategic Management Journal, 26, 809-825.

Zhao, X., Lynch Jr, J. G., \& Chen, Q. (2010). Reconsidering Baron and Kenny: Myths and truths about mediation analysis. Journal of Consumer Research, 37, 197-206. 
Zondag, M. M., \& Ferrin, B. (2014). Finding the true voice of the customer in CPG supply chains: Shopper-centric supply chain management. Journal of Business Logistics, 35, 268274. 